\title{
Mushroom Tyrosinase Inhibition and Antimelanogenesis Activities of Bacopa monnieri (L.) Methanol Extract in B16F10 Melanoma Cells
}

\author{
T. N. Shamu1, Junna Lalitha², Manohar Shinde ${ }^{1^{*}}$ \\ ${ }^{1}$ Department of Studies \& Research in Biochemistry, Tumkur University, Tumakuru, Karnataka State, India \\ ${ }^{2}$ Department of Biochemistry, Gulbarga University, Kalaburagi, Karnataka State, India \\ Email: Shamu.t.n@gmail.com, jlshinde@rediffmail.com, *drsmanohar@gmail.com
}

How to cite this paper: Shamu, T.N., Lalitha, J. and Shinde, M. (2020) Mushroom Tyrosinase Inhibition and Antimelanogenesis Activities of Bacopa monnieri (L.) Methanol Extract in B16F10 Melanoma Cells. Journal of Biosciences and Medicines, 8, 189-202. https://doi.org/10.4236/jbm.2020.85018

Received: March 30, 2020

Accepted: May 19, 2020

Published: May 22, 2020

Copyright $\odot 2020$ by author(s) and Scientific Research Publishing Inc. This work is licensed under the Creative Commons Attribution International License (CC BY 4.0).

http://creativecommons.org/licenses/by/4.0/

(c) (i) Open Access

\begin{abstract}
Melanocytes that form stratum basale of skin epidermis express tyrosinase enzyme, which catalyzes initial two rate-limiting steps in the biotransformation of tyrosine into dark pigment called melanin. Even today, Tyrosinase inhibitors are among the promising candidates in cosmetic industry for skin-lightening formulations. Overexpression of tyrosinase causes excess melanin biosynthesis and deposition resulting in dark skin color. Moreover, localized overexpression of tyrosinase cause variety of hyperpigmentation disorders like melanoma, melasma, chloasma, dark patches, liver patches, etc. There has been a renewed interest in the natural products as main ingredients in the formulation of safe products for skin-whitening and treatment options for hyperpigmentation disorders. In the present communication, the results of our investigations on tyrosinase inhibition, modulation of intracellular tyrosinase and melanin levels in cultured B16F10 melanoma cells by Bacopa monnieri (L.) methanol extract (BME) are presented and discussed as safe option for skin lightening and to treat hyperpigmentation disorders. BME showed $11 \%, 29 \%, 54 \%$ and $80 \%$ inhibition of mushroom tyrosinase activity at an initial 100, 200, 400 and $600 \mu \mathrm{g}$ of extract. Treatment of $\alpha$-melanocyte stimulating hormone ( $\alpha$-MSH) stimulated cultured murine melanoma B16F10 cells with $100 \mu \mathrm{g} / \mathrm{ml}$ of the extract showed a decrease in the levels of cellular melanin and cellular tyrosinase content by $22 \%$ and $46 \%$ respectively. The cytotoxicity studies by MTT assay revealed that the $\mathrm{LC}_{50}$ of the $\mathrm{BME}$ is $\geq 1000 \mu \mathrm{g} / \mathrm{ml}$ in cultured mouse melanoma B16F10 and HEK293 cells.
\end{abstract}

\section{Keywords}

Tyrosinase, Bacopa monieri, B16F10 Cells, Melanin, $\alpha-\mathrm{MSH}$ 


\section{Introduction}

Melanocytes, the exclusive melanin producing cells not only distributed in stratum basale of skin epidermis and hair follicles but, also in mucosa, cochlea, iris and mesencephalon [1] and are responsible for the synthesis of eumelanins that are associated with dark skin colour and hair and pheomelanin, responsible for red hair and freckled skin phenotype. Hyper-pigmentation disorders ranging from physiological phenomenon to inherited genetic disorder is a frequent clinical condition affecting quality of life of the patients and often considered as persistent burden due to limited available treatment [2]. The biology and genetics of the complex process of melanin biosynthesis, formation and maturation of melanosomes, and trafficking have been understood [3] [4]. Of the approximately 125 distinct genes known to be involved in the regulation of pigmentation, majority of genes affect development, differentiation, stabilization and survival of melanocytes and few are involved in distinct process of melanin synthesis and regulation [5] [6] [7] [8] however, tyrosinase, Tyrp1 and Dct mutations dramatically affect the quality and quantity of melanin synthesis [2]. Melanin is known to shield UV rays from the sunlight to protect the cells from photo-carcinogenesis and also from UV induced stress and inflammation by shielding the UV light [9]. Differentiation of melanocytes globally or in localized areas due to environmental or physiological stimulus results in increased melanocytes levels, which lead to overproduction of tyrosinase causing hyper-pigmentation disorders such as café au lait macules, melanoma, melisma, chloasma, Adddison's disease, acanthosis nigricans, liver patches, senile lentigens, freckles, post-inflammation hyperpigmentation, etc., [10] [11] [12]. Tyrosinase found in bacteria, fungi, plants and animals is an important enzyme involved in the biosynthesis of all kinds of melanins and is responsible for melanization in animals and enzymatic browning of damaged fruits [10] [11] [12]. The crystal structure of tyrosinase revealed that it is a multifunctional binuclear copper containing enzyme present in melanocytes of human skin wherein, the copper ions coordinate between tryptophan residue in the active site of the enzyme [13] [14].

Tyrosinase catalyzes the initial two critical rate limiting steps of hydroxylation of tyrosine (phenol) to L-DOPA (catechol) and further oxidation of L-DOPA (catechol) into (quinone), DOPAqinone [15] [16], which is an immediate precursor of yellow-orange colored pheomelanin and black brown DHI eumelanin and DHACA eumelanin [17]-[24]. The $\alpha$-melanocyte-stimulating hormone ( $\alpha$-MSH) binds to milanocortin receptor-1 (Mc1R) on melanocyte and brings about CAMP, PKA and CREB mediated activation of M promoter of Microphthalmia-associated transcription factor (MITF). Transient expression of MITF causes upregulation of tyrosinase (TYR), DOPAchrome tautomerases, tyrosinase-related protein 1 (TRP1), and tyrosinase-related protein 2 (TRP2) aiding proliferation, differentiation, melanin synthesis and dendritogenesis [25] [26].

The differential gene expressions cause dysregulation in melanin biosynthe- 
sis leading to hyper-pigmentary diseases such as, melasma, chloasma freckles, inflammatory hyperpigmentation, etc., and hypopigmentation disease like vitiligo, pityriasis alba, pityriasis versicolor, etc. in human. About more than two-third of the 4000 different skin diseases that are known to occur are associated with the change in skin color [27]. The epidemiology of pigmentary skin disease varies with the climatic condition, geographical area and the genetic composition. Melasma is by far the most widely distributed hyperpigmentation condition that affects one-third of the women population of age between 40 and 65 years [28]. Homogenous hyperpigmentation in periorbital, perilabile and nose melanosis has been observed in $80 \%$ of Indian women moreover, about $70 \%$ of the people with acne history presented pigmented post-inflammatory marks before attaining the age of 35 years [28].

Tyrosinase catalyzed reaction in melanosomes is highly associated with hypermelanogenesis and hyperpigmentary disorders that cause undesirable psychological burden. Thus, discovery of tyrosinase inhibitors for the modulation of melanogenisis pathway is of significant interest in cosmetic and medicinal products for prevention and cure of pigmentary disorders. In recent times, copper chelators, hydroquinone, kojic acid, azelic acid and arbutin, have been isolated and used in cosmetic products. Cosmetic industry is dropping hydroquinone and kojic acid due to their undesirable side effects and arbutin has poor bioavailability [29] thus, there is a great demand for the discovery of safe tyrosinase inhibitors. In this communication we report our results on the in-vitro tyrosinase inhibition, cellular tyrosinase and melanin levels in B16F10 murine melanoma cells and cytotoxicity assays of Bacopa monneri plant extract.

\section{Materials and Methods}

Chemicals: MTT (Lot No. 0000228429), PBS (Lot No. 0000251865), MEM (Lot No. 0000278156), Trypsin (Lot No. (0000234019) purchased from Hi-Media, India. Mushroom tyrosinase (Cat No. T3824, CAS RN 9002-10-2 EC 1.14.18.1) was purchased from Sigma Aldrich. Fetal Bovine Serum (Lot. No.42Q3057K) and DMSO (Lot. No. 519350205AO) were purchased from Gibco and Finar. Methanol was procured from J. T. Baker and all other solvents used were of analytical grade and procured from Spectrochem India. Bacoside A mix was procured from Natural Remedies Bengaluru. Bacopa monneri whole herb powder was purchased from Merlion Naturals, Ahmedabad.

\subsection{Extraction of Bacopa monnieri Plant Powder}

It was performed by maceration technique [30]. The dried plant powder was extracted by maceration for 3 days in methanol ( $1 \mathrm{~g}$ powder in $10 \mathrm{ml}$ methanol) and the extract filtered by a guchi filter. The filtrate obtained was further clarified by centrifugation and filtration through 0.45 -micron filter. The solvent evaporated under vacuum using a Buchi Type vacuum evaporator. The residue obtained was weighed, stored dry in a vacuum desiccator or dissolved in methanol. 


\subsection{Analysis of Total Phenolic Content}

Estimation of total polyphenol was performed by Folin-Ciocalteau reagent method [31] using gallic acid as standard. The total phenolic content expressed as percent gallic acid equivalent (GAE) in Bacopa monnieri powder.

\subsection{Analysis of Total Flavonoid Content}

Total flavonoid content was estimated by aluminium chloride-potassium acetate method [32] using luteolin as standard. The flavonoid content expressed as percent luteolin equivalent in Bacopa monnieri powder.

\subsection{Analysis of Bacopanoid Content}

Bacoponoid content of the extract was determined by vanillin-sulphuric acid method [33] using bacoside A mix as standard. Saponins content in herbal formulations were quantified and results expressed as percent bacosides A equivalent in Bacopa monnieri powder.

\subsection{DPPH Activity}

DPPH antioxidant activity was measured as suggested by Ghaffari et al. [34]. Briefly, a $950 \mu \mathrm{l}$ of methanolic solution of DPPH was mixed with $50 \mu \mathrm{l}$ extract and incubated at $37^{\circ} \mathrm{C}$ for $30 \mathrm{~min}$. The decrease in the absorbance at $517 \mathrm{~nm}$ was followed photometrically over a period of $30 \mathrm{~min}$ in a UV-Visible spectrophotometer against methanol control. Ascorbic acid was used as positive control. Results were expressed as $\mu \mathrm{g}$ ascorbic acid equivalents/mg Bacoppa monnieri methanol extract (BME).

\subsection{Tyrosinase Inhibition Assay}

Tyrosinase inhibition assay was performed by reported method [29] [35] with some modifications. The reaction mixture in a combined volume of $150 \mu \mathrm{L}$ contained 10 to $40 \mu \mathrm{l}$ inhibitor (Bacopa monnieri extract (BME), 100 - $600 \mu \mathrm{g}$ dissolved in phosphate buffer containing 0.1\% DMSO), $100 \mu \mathrm{L}$-DOPA ( $5 \mathrm{mM}$ in sodium phosphate buffer, $0.02 \mathrm{M}, \mathrm{pH} 6.9$ ), the volume was made to $140 \mu \mathrm{l}$ by adding phosphate buffer. The microwell titer plate was incubated for $5 \mathrm{~min}$ at $30^{\circ} \mathrm{C}$ to attain the assay temperature. The enzyme reaction was initiated by the addition of $2.5 \mathrm{IU}$ of mushroom tyrosinase $(10 \mu \mathrm{L})$ and the formation of DOPAchrome due to the oxidation of L-DOPA was followed at $475 \mathrm{~nm}$ at every 5 min over a period of one hour in a plate reader (Thermo Scientific). Each measurement was made in duplicate and the result presented was average of three replicate experiments. Percentage inhibition of enzyme was calculated by using the formula given below.

$$
\mathrm{IA}_{\%}=\frac{C-S}{C} \times 100
$$

IA: percentage inhibition of tyrosinase enzyme, $C$ : control without inhibitor, $S$ : plant extract. 


\subsection{Cell Culture and Test Sample Preparation}

B16F10 (Murine melanoma) cells and HEK293 cells were procured from National Centre for Cell Sciences (NCCS) Pune, India. Stock cells were cultured in DMEM supplemented with $10 \%$ inactivated Fetal Bovine Serum (FBS), penicillin (100 IU/ml), streptomycin $(100 \mu \mathrm{g} / \mathrm{ml})$ and amphotericin B $(5 \mu \mathrm{g} / \mathrm{ml})$ in a humidified atmosphere of $5 \% \mathrm{CO}_{2}$ at $37^{\circ} \mathrm{C}$ until confluent. The cells were dissociated with TPEG solution (0.2\% Trypsin, $0.02 \%$ EDTA, $0.05 \%$ glucose in PBS) and the stock cultures were grown in $25 \mathrm{~cm}^{2}$ culture flasks. All the experiments were carried out in 96 well microtitre plates (Tarsons India Pvt. Ltd.). For cytotoxicity studies, $10 \mathrm{mg}$ of Bacopa monnieri extract was weighed and dissolved by sonication in $10 \mathrm{ml}$ of DMEM supplemented with $10 \%$ inactivated FBS (w/v) to obtain a stock solution of $1 \mathrm{mg} / \mathrm{ml}$. The sample centrifuged and supernatant clarified by passing through a $0.22 \mu$ syringe filter. Serial two fold dilutions were prepared from the stock to carry out cytotoxicity studies.

\subsection{Cell Viability Assay}

The MTT assay was performed according to the reported method [36] with some modifications. The monolayer cells of freshly grown B16F10 and HEK293 were trypsinized and the cell count was adjusted to 100,000 cells/ml in DMEM containing 10\% FBS. To each well in the 96 well microtitre plate, $0.1 \mathrm{ml}$ of the diluted cell suspension was added and incubated in a humidified $5 \% \mathrm{CO}_{2}$ incubator at $37^{\circ} \mathrm{C}$. After $24 \mathrm{~h}$, when a partial monolayer was formed, the supernatants were flicked off and the monolayer washed with medium. A $100 \mu \mathrm{l}$ of different concentrations of Bacopa monnieri extract were added on to the partial monolayer in microtitre plates and cultures were incubated for $72 \mathrm{~h}$ in a humidified $5 \% \mathrm{CO}_{2}$ atmosphere at $37^{\circ} \mathrm{C}$. At the end of the incubation period, the BMEfrom the wells were discarded and $50 \mu \mathrm{l}$ of MTT in PBS was added. The plate was gently shaken and incubated for $3 \mathrm{~h}$ in $5 \% \mathrm{CO}_{2}$ atmosphere at $37^{\circ} \mathrm{C}$ the live cells reduce the tetrazole to formazan. The supernatant was then removed and $100 \mu \mathrm{l}$ of propanol was added to solubilize the formed formazan. The absorbance was measured at $540 \mathrm{~nm}$ in a microplate reader. The percent cell viability was calculated and the concentration of test drug needed to decrease the cell-viability by $50 \%$, the $\mathrm{LC}_{50}$ value, generated from the dose-response curves for each cell line.

\subsection{Measurement of Cellular Tyrosinase in Cell-Free Extract of B16F10 Melanoma Cells}

The freshly grown B16F10 cells were seeded in $60 \mathrm{~mm}$ culture dish $\left(1 \times 10^{5}\right.$ cells/dish) in DMEM containing 10\% inactivated FBS for overnight. The adhered B16F10 cells were stimulated with $\alpha$-melanocyte stimulating hormone ( $\alpha$-MSH, $100 \mathrm{nM}$ ) and simultaneously treated with or without Bacopa monnieri extract for another $24 \mathrm{~h}$ in $5 \%$ humidified $\mathrm{CO}_{2}$ environment at $37^{\circ} \mathrm{C}$. The cell-free extract was prepared by lysing the DPBS washed cell suspension $(\alpha-\mathrm{MSH}$ stimulated 
and with or without BME treated) by subjecting to a freeze thaw cycle $\left(-80^{\circ} \mathrm{C} 30\right.$ $\mathrm{min} / 25^{\circ} \mathrm{C} 25 \mathrm{~min} / 37^{\circ} \mathrm{C} 5 \mathrm{~min}$ ) in lysis buffer ( $1 \%$ Triton X-100 in $0.1 \mathrm{M}$ sodium phosphate buffer $\mathrm{pH} 6.8$, containing PMSF). The suspension centrifuged for 10 min. at $13,000 \mathrm{rpm}$ and $4^{\circ} \mathrm{C}$ and the obtained supernatant was used as cellular tyrosinase to conduct cellular tyrosinase assay. Total protein content of cell-free extract was quantified by Bradford assay using BSA as standard [36]. The tyrosinase assay was carried in a 96 well microplate by mixing $10-50 \mu \mathrm{l}$ of cell-free extract with $100 \mu \mathrm{l}$ of DOPA $(5 \mathrm{mM})$ and $50 \mu \mathrm{L}$ of DPBS. The increase in absorbance at $475 \mathrm{~nm}$ due to production of DOPAchrome was measured at every 5 min interval over a period of 1 hour at $37^{\circ} \mathrm{C}$ in a microplate reader. The cellular tyrosinase activities of $\alpha$-MSH induced B16F10 melanoma cells was assigned as $100 \%$ [37]. The in gel-tyrosinase activity was performed to evaluate the intra cellular tyrosinase levels by resolving proteins present in cell-free extracts of $\alpha$-MSH stimulated, untreated and Bacopa monnieri extract (50 $\mu \mathrm{g}$ and $100 \mu \mathrm{g} / \mathrm{ml})$ treated B16F10 melanoma cells. The gel was removed and overlaid by addition of $20 \mu \mathrm{l}$ of DOPA (10 mM in $0.02 \mathrm{M}$ phosphate buffer, $\mathrm{pH}$ 6.9) and the area of brown pigment formed was observed.

\subsection{Analysis of Cellular Melanin}

The melanin content in $\alpha$-MSH stimulated B16F10 cells with and without Bacopa monnieri extract was estimated [29]. The freshly grown B16F10 cells were seeded in 24 well plates $\left(1 \times 10^{5}\right.$ cells/well $)$ in DMEM supplemented by $10 \%$ inactivated FBS for overnight for anchorage. The anchored cells were stimulated by $\alpha$-MSH $(100 \mathrm{nM})$ and simultaneously treated with different concentrations of Bacopa monnieri methanol extract for another $72 \mathrm{~h}$. At the end of the treatment period, the cells were washed with PBS and suspended in $150 \mu \mathrm{l}$ of NaOH-DMSO solution ( $1 \mathrm{M} \mathrm{NaOH}$ containing 20\% DMSO) and lysed for $1 \mathrm{~h}$ at $80^{\circ} \mathrm{C}$. The melanin content in the lysate was estimated at $405 \mathrm{~nm}$ using a plate reader [38]. The melanin content of $\alpha$-MSH stimulated cells was assigned $100 \%$ and $\alpha$-MSH stimulated and kojic acid treated served as positive control.

\section{Results and Discussion}

The results of our investigations on total polyphenols as gallic acid equivalent, flavonoids as luteoline equivalent and saponin bacosides as bacoside A equivalent is shown in Table 1.

It is evident that the total polyphenol, flavonoid and bacopanoids content was found to be $0.76 \%, 0.19 \%$ and $2.8 \%$ respectively in Bacopa monnieri powder.

Table 1. The total polyphenol, flavonoid and bacoponoid content in the Bacopa monnieri powder.

\begin{tabular}{cccc}
\hline S1 No. & $\begin{array}{c}\text { Total polyphenol as \% } \\
\text { gallic acid equivalent in } \\
\text { Bacopa monnieri powder }\end{array}$ & $\begin{array}{c}\text { Total flavonoid as \% } \\
\text { leutioline equivalent in } \\
\text { Bacopa monnieri powder }\end{array}$ & $\begin{array}{c}\text { Total Bacopanoid (\%) in } \\
\text { Bacopa monnieri powder }\end{array}$ \\
\hline 1 & 0.76 & 0.19 & 2.8 \\
\hline
\end{tabular}




\subsection{DPPH Antioxidant Capacity}

The DPPH radical scavenging capacity was estimated to $19.22 \% \pm 0.01 \%$, which is equivalent to $2.23 \mu \mathrm{g}$ ascorbic acid equivalent/mg Bacopa monnieri powder.

\subsection{Tyrosinase Inhibition Assay}

The effect of Bacopa monnieri methanolic extract (BME) on the tyrosinase activity was studied at different initial concentrations of BME in a 96 well assay plate. The results are depicted in Figure 1. The photograph presented in the figure clearly shows the BME caused the inhibition in the activity of tyrosinase in a dose dependent manner. The inhibition of tyrosinase increased with the increase in the concentration of BME.

The results on the percent residual tyrosinase activity and percent inhibition of tyrosinase activity by different initial concentrations of methanol extract of Bacopa monnieri is presented in Figure 2 and Figure 3.

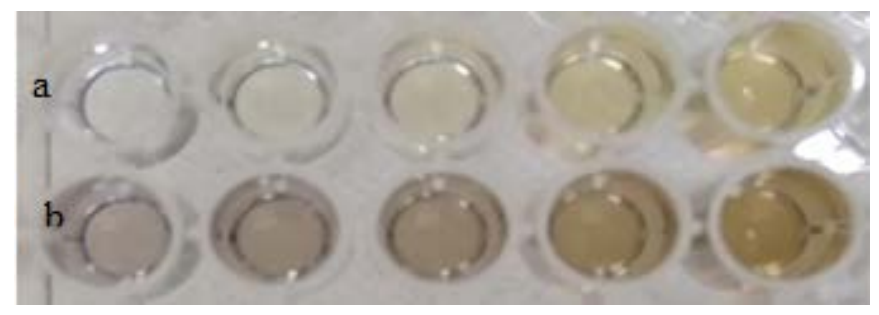

Figure 1. Tyrosinase inhibition assay (a) Test with Bacopa monnieri methanol extract and (b) control without Bacopa monnieri extract.
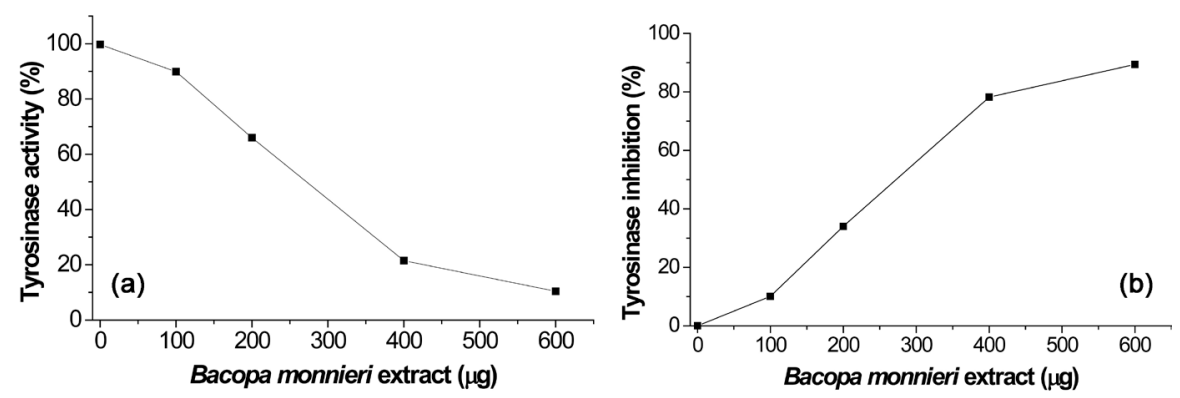

Figure 2. Effect of different concentrations of methanol extract of Bacopa monnieri on (a) mushroom tyrosinase activity (IU) and (b) percent inhibition of mushroom tyrosinase activity.
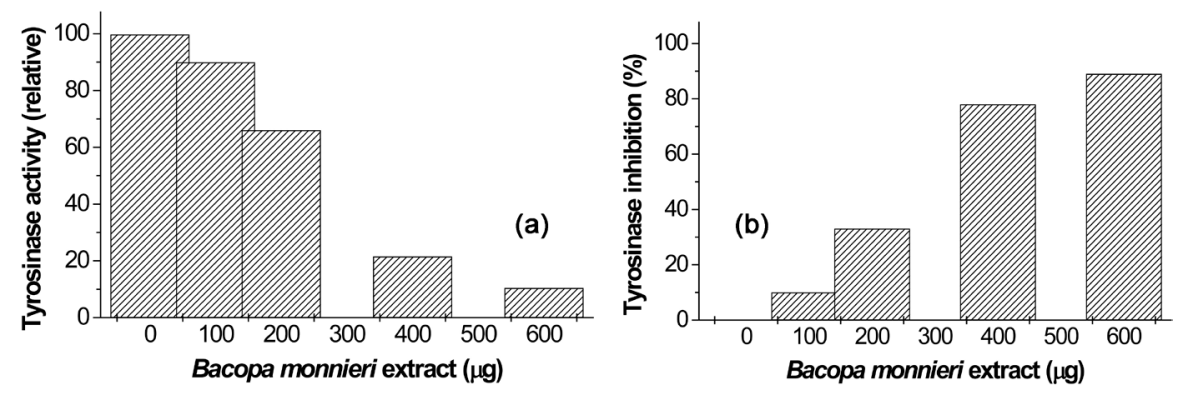

Figure 3. Bar diagram showing influence of Bacopa monnieri methanol extract on (a) mushroom tyrosinase activity and (b) percent inhibition of mushroom tyrosinase activity. 
The results presented in Figure 1 and Figure 2 show that the methanolic extracts of Bacopa monnieri inhibits mushroom tyrosinase activity in dose dependent manner. It is evident from Figure 1 and Figure 2 that an initial 100, 200, 400 and $600 \mu \mathrm{g}$ of methanol extract of Bacopa monnieri inhibited 10, 33, 78 and $89 \%$ of mushroom tyrosinase activity respectively. The $50 \%$ inhibitory concentration $\left(\mathrm{IC}_{50}\right)$ value of Bacopa monnieri methanol extracts was calculated to be $372 \mu \mathrm{g} / \mathrm{ml}$.

\subsection{Cell Proliferation and Cytotoxicity Assay}

The MTT assay was performed to calculate the $50 \%$ lethal concentration $\left(\mathrm{LC}_{50}\right)$ of Bacopa monnieri methanol extract that reduces 50\% viability of cultured B16F10 mouse melanoma cell line and HEK293 cells. The results on the $\mathrm{LC}_{50}$ value of BME are presented in Table 2 and Figure 4.

The B16F10 cells and HEK293 cells were cultured in 96 well plates in DMEM containing $10 \% \mathrm{FBS}$ for $24 \mathrm{~h}$ in $5 \% \mathrm{CO}_{2}$ environment at $37^{\circ} \mathrm{C}$ and the medium discarded. The cells were then added with different test concentrations of Bacopa monnieri extract ( 7.8 to $1000 \mu \mathrm{g} / \mathrm{ml}$ ) in DMEM supplemented by $10 \%$ FBS and the culture plate incubated in a humidified $5 \% \mathrm{CO}_{2}$ incubator at $37^{\circ} \mathrm{C}$ for another $48 \mathrm{~h}$. It is evident from the table that the $50 \%$ cell cytotoxicity concentration $\left(\mathrm{LC}_{50}\right)$ of methanol extract of Bacopa monnieri for both B16F10 mouse melanoma and HEK293 cells exceeds $1000 \mu \mathrm{g} / \mathrm{ml}$.

Table 2. MTT assay to determine the $\mathrm{LC}_{50}$ of methanol extract of Bacopa monnieri (BME) using B16F10 murine melanoma cell lines and HEK293 cells.

\begin{tabular}{lcccc}
\hline Test Compound & $\begin{array}{c}\text { Bacopa monneri } \\
\text { extract }(\mu \mathrm{g} / \mathrm{ml})\end{array}$ & $\begin{array}{c}\text { \% Cytotoxicity } \\
\text { B16F10 }\end{array}$ & $\begin{array}{c}\text { \% Cytotoxicity } \\
\text { HEK293 }\end{array}$ & $\begin{array}{c}\text { LC }_{50} \\
(\mu \mathrm{g} / \mathrm{ml})\end{array}$ \\
\hline & 1000 & $34.04 \pm 0.30$ & $5.22 \pm 0.42$ & \\
Bacopa monnieri & 125 & $20.90 \pm 0.36$ & 2.8 & 1.2 \\
methanol extract & 62.5 & $12.93 \pm 0.31$ & --- & $\geq 1000$ \\
& 31.2 & $8.20 \pm 0.42$ & --- & \\
& 15.6 & $5.4 \pm 0.42$ & --- & \\
\hline
\end{tabular}
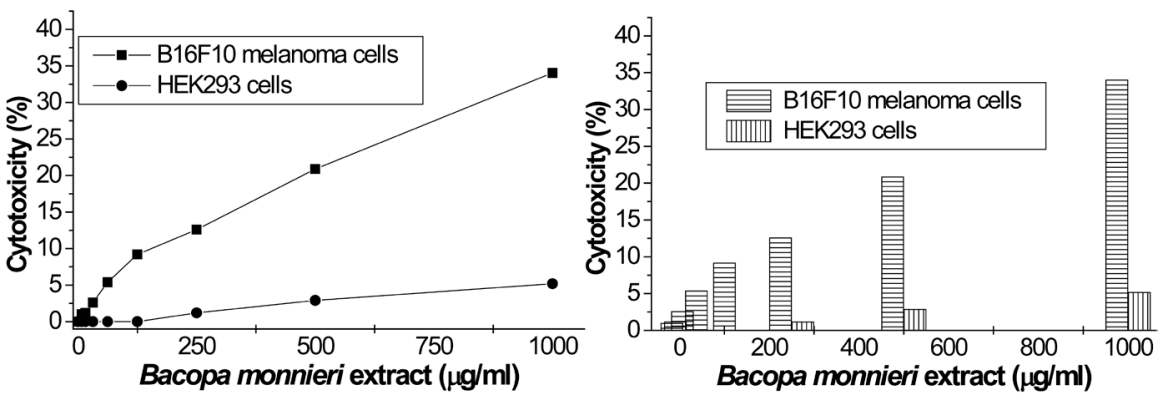

Figure 4. The MTT assay to test the $\mathrm{LC}_{50}$ value of $\mathrm{BME}$ on $\mathrm{B} 16 \mathrm{~F} 10$ melanoma cell line and HEK293 cells. The $\mathrm{LC}_{50}$ concentration of BME exceeds $1000 \mu \mathrm{g} / \mathrm{ml}$. 


\subsection{Determination of Intracellular Tyrosinase Activity in Cultured B16F10 Melanoma Cells}

The analysis of intracellular tyrosinase activity in cell-free extracts of $\alpha$-MSH stimulated B16F10 melanoma cells treated with and without Bacopa monnieri methanol extract was carried out and the results are depicted in Table 3 and Figure 5.

It is evident from Table 3 and Figure 5 that the Bacopa monnieri extract decreases the tyrosinase and melanin content in cultured B16F10 mouse melanoma cell line. The cell-free extracts of $\alpha-\mathrm{MSH}$ stimulated B16F10 mouse melanoma cells treated with 50 and $100 \mu \mathrm{g} / \mathrm{ml}$ Bacopa monnieri extract showed 59.4 and $53.5 \%$ of residual intracellular tyrosinase levels as compared to that of the control cells (cell-free extracts of $\alpha$-MSH stimulated B16F10 cells). The decrease in the cellular tyrosinase activity in $\alpha$-MSH stimulated B16F10 cells treated with 50 and $100 \mu \mathrm{g} / \mathrm{ml}$ Bacopa monnieri extract was calculated to be $40.6 \%$ and $46.5 \%$ as compared to that of the $\alpha$-MSH stimulated control cells. The $\alpha$-MSH stimulated B16F10 mouse melanoma cells showed 22\% reduction in cellular melanin content after treatment with $100 \mu \mathrm{g} / \mathrm{ml}$ Bacopa monnieri extract.

In-gel tyrosinase activity: The cell-free extracts of $\alpha$-MSH stimulated B16F10 cells (control and treated) were resolved on ND-PAGE and the electrogram was flooded with DOPA (10 mM, $20 \mu \mathrm{l} / \mathrm{spot})$, incubated for I hr and results observed. The thickness of brown-black melanin pigment formed after flooding the chromatogram with DOPA suggested that the tyrosinase levels in the cell-free extracts of $\alpha$-MSH stimulated and Bacopa monnieri treated cells decreased as it is compared to that of the $\alpha$-MSH stimulated cell control (data not shown).

Table 3. Influence of Bacopa monnieri extract on the levels of intracellular tyrosinase of $\alpha$-MSH stimulated B16F10 mouse melanoma cell lines.

\begin{tabular}{cccc}
\hline $\begin{array}{c}\text { Sl. } \\
\text { No. }\end{array}$ & Sample & $\begin{array}{c}\text { Test concentration } \\
(\mu \mathrm{g} / \mathrm{mL})\end{array}$ & $\begin{array}{c}\text { \% intracellular tyrosinase in } \alpha \text {-MSH } \\
(100 \mathrm{nM})\end{array}$ \\
\hline 1 & Nil (control) & Nil & 100 \\
& & 100 & $53.5 \pm 1.51$ \\
2 & Bacopa monnieri extract & 50 & $59.4 \pm 1.67$ \\
& & 100 & $43.5 \pm 3.32$ \\
\hline
\end{tabular}
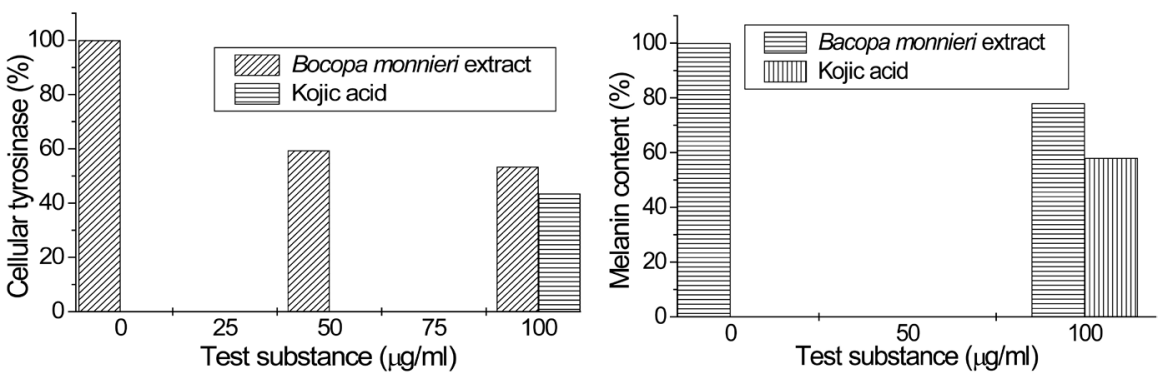

Figure 5. Intracellular tyrosinase assay and melanin content in cultured B16F10 melanoma cells stimulated with $\alpha$-MSH and treated with methanolic extract of Bacopa monnieri and Kojic acid. 
Bhardwaj et al., [30] and [39] conducted studies on the estimation of phytochemical content in Bacopa monnieri herb from different locations of India. The total polyphenol content, flavonoid content and bacopanoid saponin content in Bacopa monnieri was reported to be in the range of $0.33 \%$ to $0.91 \% ; 0.11 \%$ to $0.4 \%$ and $1.6 \%$ to $3.8 \%$ respectively in natural herb and $1 \%$ to $5.5 \% ; 0.5 \%$ to $1 \%$ and $9.8 \%$ to $15.7 \%$ in in-vitro propagated and field acclimatized Bacopa monnieri plants [30] [39]. Our results on the total polyphenols, flavonoids and bacopanoids in Bacopa monnieri herb powder extracts are in accordance with that of [30] [39]. The macerated methanol extract of Bacopa monnieri plant powder showed considerable levels of phenols (0.76\%), flavonoids $(0.19 \%)$, bacoponoids (2.8\%) and also showed good antioxidant capacity.

The tyrosinase inhibitory and antimelanogenic activities are reported in different natural products. Lin et al., [38] reported the antimelanogenic property of raspberry-ketone without inhibiting tyrosinase. Xie et al., [40] and Nitoda et al., [41] reported mushroom tyrosinase inhibition and antimelanogenic acitivity in B16F10 cells respectively by quercetin, whereas, Nagata et al., [42] reports enhanced melanogenesis by quercetin by increased tyrosinase production in human melanoma cells and in normal human melanocytes. Our results on tyrosinase inhibition by Bacopa monnieri extract are in accordance with [40] [41] however, in the present investigation up to $80 \%$ inhibition in mushroom tyrosinase was observed. In a similar study, despite increased production of cellular tyrosinase, taxifolin and luteolin, attenuate cellular melanogenesis [43]. Kim et al., [44] reported calycosin extracted from Astragalus membranaceus roots inhibited melanin biosynthesis whereas, biochanin A caused in-vitro and in-vivo melanogenesis inhibition [45]. The Bacopa extract studied in the present investigation inhibited tyrosinase in dose dependent manner as well as caused decrease in the intracellular melanin and tyrosinase levels in $\alpha$-MSH stimulated B16F10 melanoma cell model by 22 and $46 \%$.

Purified 2,5-dihydroxyacetophenone from Cynanchum bungei was found to inhibit murine tyrosinase and also exhibited in-vitro and in-vivo depigmentation activity [46], whereas, linderanolide B and subamolide A from Cinnamomum subavenium [47] inhibited human tyrosinase caused antimelanogenesis.

The B16F10 cells have long been used as model for the discovery of antimelanogenic principles, mainly because it shares mechanism of melanogenesis of normal human melanocyte and also because the cells can be easily cultured in vitro. The proopiomelanocortin derived peptide hormone $\alpha$-MSH, by binding to melanocortin receptor (MC1R) regulates melanogenesis via cAMP-dependent pathway, activating protein kinase A and affecting expression of MITF, which stimulates melanogenesis by activating melanogenesis specific enzymes [48] [49]. Chang et al., [50] reported melanogenesis inhibitors act by downregulation of tyrosinase. Our results on the tyrosinase inhibition by Bacopa monnieri extract are in accordance with that of Chang et al., (2012), however, the Bacopa monnieri extract in addition to tyrosinase inhibition was found to downregulate intracellular tyrosinase and melanin levels. 


\section{Conclusion}

The macerated methanol extract of Bacopa monnieri plant powder showed considerable levels of phenols $(0.76 \%)$, flavonoids $(0.19 \%)$ and bacoponoids $(2.8 \%)$ and also exhibited good antioxidant capacity. The Bacopa monnieri extract was found to be safe $\left(\mathrm{LC}_{50}\right.$ value $\left.\geq 1000 \mu \mathrm{g} / \mathrm{ml}\right)$ and not only inhibited tyrosinase activity but, was able to downregulate intracellular melanin and tyrosinase in $\alpha$-MSH stimulated cultured B16F10 cells. Bacopa monnieri powder and extract is an Ayurveda formulation available over the counter in India as a memory enhancer. Therefore, it has great potential for its application as a major ingredient in the formulations for skin-lightening and to treat hyperpigmentation disorders.

\section{Acknowledgements}

Authors are thankful to Tumkur University, Tumkur India, Gulbarga University, Kalaburagi India and Radiant research for providing facilities.

\section{Conflicts of Interest}

The authors declare no conflicts of interest regarding the publication of this paper.

\section{References}

[1] Yamaguchi, Y. and Hearing, V.J. (2014) Melanocytes and Their Diseases. Cold Spring Harbor Perspectives in Medicine, 4, Article ID: 017046. https://doi.org/10.1101/cshperspect.a017046

[2] Speeckaert, R., Gele, M.V., Speeckaert, M.M., Lambert, J. and Geel, N.V. (2014) The Biology of Hyperpigmentation Syndromes. Pigment Cell \& Melanoma Research, 27, 512-524. https://doi.org/10.1111/pcmr.12235

[3] Wu, X. and Hammer, J.A. (2000) Making Sense of Melanosome Dynamics in Mouse Melanocytes. Pigment Cell \& Melanoma Research, 13, 241-247. https://doi.org/10.1034/j.1600-0749.2000.130405.x

[4] Coudrier, E. (2007) Myosins in Melanocytes: To Move or No to Move? Pigment Cell \& Melanoma Research, 20, 153-160. https://doi.org/10.1111/j.1600-0749.2007.00376.x

[5] Bennett, D.C. and Lamoreux, M.L. (2003) The Colour Loci of Mice: Agenetic Century. Pigment Cell \& Melanoma Research, 16, 333-344. https://doi.org/10.1034/j.1600-0749.2003.00067.x

[6] Kushimoto, T., Valencia, J.C., Costin, G.E., Toyofuku, K., Watabe, H., Yasumoto. K., Rouzaud, F., Vieira, W.D. and Hearing, V.J. (2003) The Melanosome: An Ideal Model to Study Cellular Differentiation. Pigment Cell \& Melanoma Research, 16, 237-244. https://doi.org/10.1034/j.1600-0749.2003.00034.x

[7] Chi, A., Valencia, J.C., Hu, Z.Z., Watabe, H., Yamaguchi, H., Mangini, N., Huang, H., Canfield, V.A., Cheng, K.C., Yang, F., Abe, R., Yamagishi, S., Shabanowitz, J., Hearing, V.J., Wu, C.H., Appella, E. and Hunt, D.F. (2006) Proteomic and Bioinformatics Characterization of the Biogenesis and Function of Melanosomes. Journal of Proteome Research, 5, 3135-3144. https://doi.org/10.1021/pr060363j

[8] Hu, Z., Valencia, J.C., Huang, H., Chi, A., Shabanowitz, J., Hearing, V.J., Appella, E. and $\mathrm{Wu}, \mathrm{C}$. (2007) Comparative Bioinformatics Analysis and Profiling of Ly- 
sosome-Related Organelle Proteomes. International Journal of Mass Spectrometry, 259, 147-160. https://doi.org/10.1016/j.ijms.2006.09.024

[9] Lindquist, N.G. (1973) Accumulation of Drugs on Melanin. Acta radiologica: Diagnosis, 325, 1-92.

[10] Briganti, S., Camera, E. and Picardo, M. (2003) Chemical and Instrumental Approaches to Treat Hyperpigmentation. Pigment Cell \& Melanoma Research, 16, 101-110. https://doi.org/10.1034/j.1600-0749.2003.00029.x

[11] Solano, F., Briganti, S., Picardo, M. and Ghanem, G. (2006) Hypopigmenting Agents: An Updated Review on Biological, Chemical and Clinical Aspects. Pigment Cell \& Melanoma Research, 19, 550-571. https://doi.org/10.1111/j.1600-0749.2006.00334.x

[12] Kim, C.S., Noh, S.G., Park, Y., Kang, D., Chun, P., Chung, H.Y., Jung, H.J. and Moon, H.R. (2018) A Potent Tyrosinase Inhibitor, (E)-3-(2,4-Dihydroxyphenyl)-1(Thiophen-2-yl)-Prop2-en-1-One, with Anti-Melanogenesis Properties in $\alpha$-MSH and IBMX-Induced B16F10 Melanoma Cells. Molecules, 23, 2725. https://doi.org/10.3390/molecules23102725

[13] Matoba, Y., Kumagai, T., Yamamoto, A., Yoshitsu, H. and Sugiyama, M. (2006) Crystallographic Evidence That the Dinuclear Copper Center of Tyrosinase Is Flexible during Catalysis. The Journal of Biological Chemistry, 281, 8981-8990. https://doi.org/10.1074/jbc.M509785200

[14] Ismaya, W.T., Rozeboom, H.J., Weijn, A., Mes, J.J., Fusetti, F., Wichers, H.J. and Dijkstra, B.W. (2011) Crystal Structure of Agaricus bisporus Mushroom Tyrosinase: Identity of the Tetramer Subunits and Interaction with Tropolone. American Chemical Society, 50, 5477-5486. https://doi.org/10.1021/bi200395t

[15] Pawelek, J.M. and Korner, A.M. (1982) The Biosynthesis of Mammalian Melanin. American Scientist, 70, 136-145.

[16] Wakamatsu, K., Kavanagh, R., Kadekaro, A.L., Terzieva, S., Sturm, R.A., Leachman, S., Abdel-Malek, Z. and Ito, S. (2006) Diversity of Pigmentation in Cultured Human Melanocytes Is Due to Differences in the Type as Well as Quantity of Melanin. Pigment Cell \& Melanoma Research, 19, 154-162. https://doi.org/10.1111/j.1600-0749.2006.00293.x

[17] Cass, A.E. and Hill, H.A. (1980) Copper Proteins and Copper Enzymes. Ciba Foundation Symposium, 79, 71-91. https://doi.org/10.1002/9780470720622.ch5

[18] Passi, S. and Nazzaro-Porro, M. (1981) Molecular Basis of Substrate and Inhibitory Specificity of Tyrosinase: Phenolic Compounds. British Journal of Dermatology, 104, 659-665. https://doi.org/10.1111/j.1365-2133.1981.tb00752.x

[19] Cabanes, J., Garcia-Canovas, F., Lozano, J.A. and Garcia-Carmona, F.A, (1987) Kinetic Study of the Melanization Pathway between L-Tyrosine and Dopachrome. Biochimica et Biophysica Acta, 923, 187-195. https://doi.org/10.1016/0304-4165(87)90003-1

[20] Spritz, R.A. and Hearing Jr., V.J. (1994). Genetic Disorders of Pigmentation. Advances in Human Genetics, 22, 1-45. https://doi.org/10.1007/978-1-4757-9062-7_1

[21] Prota, G. (1988) Progress in the Chemistry of Melanins and Related Metabolites. Medicinal Research Reviews, 8, 525-556. https://doi.org/10.1002/med.2610080405

[22] Seo, S.Y., Sharma, V.K. and Sharma, N. (2003) Mushroom Tyrosinase: Recent Prospects. Journal of Agricultural and Food Chemistry, 51, 2837-2853. https://doi.org/10.1021/jf020826f

[23] Ito, S. (2003) A Chemist View of Melanogenesis. Pigment Cell \& Melanoma Research, 16, 230-236. https://doi.org/10.1034/j.1600-0749.2003.00037.x 
[24] Slominski, A., Tobin, D.J., Shibahara, S. and Wortsman, J. (2004) Melanin Pigmentation in Mammalian Skin and Its Hormonal Regulation. Physiological Reviews, 84, 1155-1228. https://doi.org/10.1152/physrev.00044.2003

[25] Bertolotto, C., Busca, R., Abbe, P., Bille, K., Aberdam, E., Ortonne, J.P. and Ballotti, R. (1998) Different CIS-Acting Elements Are Involved in the Regulation of TRP1 and TRP2 Promoter Activities by Cyclic AMP: Pivotal Role of M Boxes (GTCATGTGCT) and of Microphthalmia. Molecular and Cellular Biology, 18, 694-702. https://doi.org/10.1128/MCB.18.2.694

[26] Hirobe, T. (2011) How Are Proliferation and Differentiation of Melanocytes Regulated? Pigment Cell \& Melanoma Research, 24, 462-478. https://doi.org/10.1111/j.1755-148X.2011.00845.x

[27] Dogra, S. and Sarangal, R. (2014) Pigmentary Disorders: An Insight. Pigment International, 1, 5-7. https://doi.org/10.4103/2349-5847.135429

[28] Hourblin, V., Nouveau, S., Roy, N. and De-Lacharriere, O. (2014) Skin Complexion ND Pigmentary Disorders in Facial Skin of 1204 Women in 4 Indian Cities. Indian Journal of Dermatology, Venereology and Leprology, 80, 395-401. https://doi.org/10.4103/0378-6323.140290

[29] Chen, W.C., Tseng, T.S., Hsiao, N.W., Lin, Y.L., Wen, Z.H., Tsai, C.C., Lee, Y.C., Lin, H.H. and Tsai, K.C. (2015) Discovery of Highly Potent Tyrosinase Inhibitor, T1, with Significant Anti-Melanogenesis Ability by Zebrafish in Vivo Assay and Computational Molecular Modelling. Scientific Reports, 5, 7995. https://doi.org/10.1038/srep07995

[30] Bhardwaj, P., Jain, C.K. and Mathur, A. (2016) Comparative Qualitative and Quantitative Analysis of Phytochemicals in Five Different Herbal Formulations of Bacopa monnieri. International Journal of Pharmacognosy and Phytochemical Research, $\mathbf{8}$, 675-682.

[31] Singleton, V.L., Orthofer, R. and Lamuela-Raventos, R.M. (1999) Analysis of Total Polyphenol and Other Oxidation Substrates and Antioxidants by Means of Folin-Ciocalteu Reagent. Methods in Enzymology, 299, 152-178. https://doi.org/10.1016/S0076-6879(99)99017-1

[32] Chang, C.C., Yang, M.H. and Chen, J.C. (2002) Estimation of Total Flavonoid Content in Propolis by Two Complementary Colorimetric Methods. Journal of Food and Drug Analysis, 10, 178-182.

[33] Hiai, S., Oura, H. and Nakajima, T. (1976). Color Reaction of Some Sapogenins and Saponins with Vanillin Sulfuric Acid. Planta Medica, 29, 116-122.

https://doi.org/10.1055/s-0028-1097639

[34] Ghaffari, H., Ghassam, B.J., Nayaka, S.C., Kini, K.R. and Prakash, H. S. (2014). Antioxidant and Neuroprotective Activities of Hyptis Suaveolens (L) Poit against Oxidative Stress Induced Neurotoxicity. Cellular and Molecular Neurobiology, 34, 323-331. https://doi.org/10.1007/s10571-013-0016-7

[35] Teixeira, R.S., Rocha, P.R., Polonini, H.C., Brandão, M.A.F., Chaves, M.G.A.M. and Raposo, N.R.B. (2012) Mushroom Tyrosinase Inhibitory Activity and Major Fatty Acid Constituents of Amazonian Native Flora Oils. Brazilian Journal of Pharmaceutical Sciences, 48, 399-404. https://doi.org/10.1590/S1984-82502012000300006

[36] Mosmann, T. (1983) Rapid Colorimetric Assay for Cellular Growth and Survival: Application to Proliferation and Cytotoxicity Assays. The Journal of Immunological Methods, 65, 55-63. https://doi.org/10.1016/0022-1759(83)90303-4

[37] Bradford, M. (1976) A Rapid and Sensitive Method Test for the Quantification of Microgram Quantities of Protein Utilizing the Principle of Protein-Dye Binding. 
Analytical Biochemistry, 72, 248-254.

https://doi.org/10.1016/0003-2697(76)90527-3

[38] Lin, V.C., Ding H.Y., Kuo S.Y., Chin, L.W., Wu, J.Y. and Chang, T.S (2011) Evaluation of in Vitro and in Vivo Depigmenting Activity of Raspberry Ketone from Rheum officinale. International Journal of Molecular Sciences, 12, 4819-4835. https://doi.org/10.3390/ijms12084819

[39] Bhardwaj, P, Jain, C.K. and Mathur, A. (2019) Comparative Analysis of Saponins, Flavonoids, Phenols and Antioxidant Activities of Field Acclimatized in-Vitro and Propagated Bacopa monnieri (L) Pannel from Different Locations of India. Indian Journal of Experimental Biology, 57, 259-268.

[40] Xie, L.P., Chen, Q.X., Huang, H., Wang, H.Z. and Zhang, R.Q. (2003) Inhibitory Effects of Some Flavonoids on the Activity of Mushroom Tyrosinase. Biochemistry, 68, 487-491.

[41] Nitoda, T., Isobe, T. and Kubo, I. (2008) Effects of Phenolic Compounds Isolated from Rabdosia japonica on B16-F10 Melanoma Cells. Phytotherapy Research, 22, 867-872. https://doi.org/10.1002/ptr.2373

[42] Nagata, H., Takekoshi, S., Takeyama, R. and Homma, T. (2004) Quercetin Enhances Melanogenesis by Increasing the Activity and Synthesis of Tyrosinase in Human Melanoma Cells and in Normal Human Melanocytes. Pigment Cell \& Melanoma Research, 17, 66-73. https://doi.org/10.1046/j.1600-0749.2003.00113.x

[43] An, S.M.., Kim, H.J., Kim, J.E. and Boo, Y.C. (2008) Flavonoids, Taxifolin and Luteolin Attenuate Cellular Melanogenesis Despite Increasing Tyrosinase Protein Level. Phytotherapy Research, 22, 1200-1207. https://doi.org/10.1002/ptr.2435

[44] Kim, J.K., Kim, R.R., Lee, E.S. and Lee, C.H. (2009) Inhibitory Effects of Calycosin Isolated from the Root of Astragalus membranaceus on Melanin Biosynthesis. Biological and Pharmaceutical Bulletin, 32, 264-268. https://doi.org/10.1248/bpb.32.264

[45] Lin, V.C., Ding, H.Y., Tasi, P.C., Wu, J.Y., Lu, Y.H. and Chang, T.S. (2011) In Vitro and in Vivo Melanogenesis Inhibition by Biochanin A from Trifolium pretense. Bioscience, Biotechnology, and Biochemistry, 75, 914-918. https://doi.org/10.1271/bbb.100878

[46] Ding, H.Y., Chang, T.S., Shen, H.C. and Tai, S.S.K. (2011) Murine tyrosinase Inhibitors from Cynanchum bungei and Evaluation of in Vitro and in Vivo Depigmenting Activity. Experimental Dermatology, 20, 720-724. https://doi.org/10.1111/j.1600-0625.2011.01302.x

[47] Wang, H.M., Chen, C.Y. and Wen, Z.H. (2011) Identifying Melanogenesis Inhibitors from Cinnamomum subavenium with in Vitro and in Vivo Screening Systems by Targeting the Human Tyrosinase. Experimental Dermatology, 20, 242-248. https://doi.org/10.1111/j.1600-0625.2010.01161.x

[48] Hunt, G., Todd, C., Cresswell, J.E. and Thody, A.J. (1994) $\alpha$-Melanocyte Stimulating Hormone and Its Analogue Nle4DPhe7 Alpha-MSH Affect Morphology, Tyrosinase Activity and Melanogenesis in Cultured Human Melanocytes. Journal of Cell Science, 107, 205-211.

[49] Busca, R. and Ballotti, R. (2000) Cyclic AMP a Key Messenger in the Regulation of Skin Pigmentation. Pigment Cell \& Melanoma Research, 13, 60-69. https://doi.org/10.1034/j.1600-0749.2000.130203.x

[50] Chang, T.S. (2012) Natural Melanogenesis Inhibitors Acting through the DownRegulation of Tyrosinase Activity. Materials, 5, 1661-1685.

https://doi.org/10.3390/ma5091661 